\title{
The use of Elaboration Likelihood Model in eWOM re- search: literature review and weight-analysis
}

\author{
Elvira Ismagilova ${ }^{[1]}$, Yogesh Dwivedi ${ }^{[2]}$, and Nripendra Rana ${ }^{[1]}$ \\ ${ }^{1}$ Faculty of Management, Law and Social Sciences, University of Bradford, \\ Bradford, UK \\ \{e.ismagilova,n.p.rana\}@bradford.ac.uk \\ ${ }^{2}$ Emerging Markets Research Centre, School of Management, \\ Swansea University, Swansea, UK \\ y.k.dwivedi@swansea.ac.uk
}

\begin{abstract}
With the development of Internet and e-commerce, traditional word of mouth communications have evolved into electronic word of mouth (eWOM) communications, which significantly affect consumers in their decision-making process. Previous studies investigated how consumers process information online and how it affects consumer behaviour applying the Elaboration Likelihood Model (ELM). ELM distinguishes between two routes of information processing: central and peripheral. Existing literature has a mixed of findings regarding factors affecting information process using ELM and lacking a comprehensive review providing evaluation and a consolidated view of these factors. Thus, the aim of this research is to evaluate the use of ELM in the context of eWOM research by performing a systematic review and weight analysis of existing research findings. This will help consolidating the predictive power of the independent variables on the dependent variable, by taking into consideration the number of times a relationship has been previously examined. The model developed through weight analysis would allow eWOM practitioners to decipher more influential factors.
\end{abstract}

Keywords: eWOM, ELM, weight analysis, eWOM persuasiveness, literature review

\section{Introduction}

Developed from traditional word of mouth communications, Electronic word-ofmouth (eWOM) communications represent one of the most important information sources used by consumers in their decision-making process [1]. eWOM is defined as "the dynamic and on-going information exchange process between potential, actual, or former consumers regarding a product, service, brand, or company, which is available to a multitude of people and institutions via the Internet" [2]. eWOM has unique characteristics (e.g. tie strength, privacy, anonymity, volume), which makes its processing more complicated in comparison with traditional WOM [3].

eWOM communications receive growing interest from researchers and practitioners [2]. eWOM significantly affects the consumer decision-making process. According to recent statistics, online reviews, which are types of eWOM influence the purchase 
decision for 93 percent of consumers [4]. A number of studies investigated factors affecting the persuasiveness of eWOM and its impact on consumer behaviour. To explain the information processing, researchers used Elaboration Likelihood Model (ELM). ELM is considered as the most popular and useful persuasion model in consumer research and social psychology [5]. According to ELM individuals process information using central and peripheral routes. The topic of ELM studies in the context of eWOM communications is still relatively new. Few existing studies provided a comprehensive literature review of the application of ELM model in information processing but did not consider it in the context of eWOM communications [5, 6]. The extant literate on ELM studies in eWOM environment appeared fragmented without a comprehensive review of published papers or a classification framework. Thus, it is not easy to draw meaningful conclusions from prior studies due to inconsistent results and lack of their consolidated understanding. Existing studies in this area have reported conflicting results on the effect of factors on persuasion and consumer behaviour. For example, Kim and Lee [7] found that source credibility has a significant positive effect on intention to buy, while Wang [8] found that the effect is non-significant. The difference in the results might be explained by different types of products and services, as well as different platform characteristics. The mixed findings on the factors affecting perceived persuasiveness of eWOM communications and consumer behaviour can lead to confusion for academics and marketing practitioners alike.

As a result, it is important to conduct a review of existing ELM studies in eWOM context and perform weight-analysis. Hence, the purpose of this research is to evaluate the use of ELM in the context of eWOM research by performing a systematic review and weight analysis of existing research findings. This will help investigate the predictive power of the independent variables on the dependent variable, by taking into consideration the number of times a relationship has been previously examined. The model developed through weight analysis would allow eWOM practitioners to decipher more influential factors.

The remainder of the paper is organised as follows. First, the literature review will be presented. After, the research method employed for this study is described. Next, the findings from weight analysis are presented. Then, the findings are discussed, followed by the conclusion and outlining the limitations of this study and directions for future research.

\section{$2 \quad$ Literature Review}

ELM was proposed by Petty and Cacioppo [9]. It is a dual process theory which describes the change of attitude form. The model explains different ways of stimuli processing. ELM separates the central route (when an individual considers an idea logically) and peripheral route (where an individual employs pre-existing ideas and superficial qualities to be persuaded by the message) [9]. Individuals use the central route when they are motivated and can think about the issue (high involvement consumers). Opposite to central route, the peripheral route is used when either ability or motivation to think on the issue is low (low involvement consumers) [9, 10]. ELM is 
used in the information adoption model proposed by Sussman and Siegal [11]. The information adoption model states that information helpfulness will influence outcomes (e.g. intention towards and advocated behaviour). ELM is considered as a major theoretical model in eWOM research [12].

Existing studies in eWOM communications mostly consider ELM by using central or peripheral cues to process information [10,12,13]. Existing literature states that information embedded in eWOM message is centrally processed by consumers, whilst information associated with text attributes such as reviewer characteristics is heuristically processed by individuals [14]. Studies defined argument quality, accuracy, factuality, valence, timeliness, type of review, length, readability, and relevance as the central route [15-18]. Whilst average rating, consistency, expertise, image, number of followers, number of friends, presentation mode, credibility, tie strength, and volume were defined as a peripheral route [19-22].

\section{$3 \quad$ Research method}

As this research aims to synthesise existing findings on the use of ELM in eWOM research, it was considered appropriate to employ weight analysis [23, 24]. Weight analysis is used to ascertain the predictive power of independent variables taking into account the number of times the relationships between independent and dependent variables were studied before.

To perform the analysis, peer-reviewed journal articles on eWOM communications were collected from bibliographic databases Scopus, EBSCO and Web of Science using a keyword search based approach [25-27]. The searched keywords included "Elaboration likelihood model", "ELM", "Online review", "Online reviews", "Electronic word-of-mouth", "Electronic word of mouth", "eWOM", "Internet word-ofmouth", "Internet word of mouth", "iWOM", "Online word-of-mouth", "Online word of mouth", "Virtual word-of-mouth". As a result of this search 120 articles were identified. Articles that did not have empirical findings were excluded, leaving 75 articles. Based on the screening and initial review of these 75 articles, Table 1 presents the factors (as constructs or dimensions of ELM) affecting consumer behavior that were used in eWOM studies.

Based on the analysis of 75 articles, it was found that researchers used a number of moderators, which affected the impact of peripheral and central cues on information processing. The most common used moderators are product type [28, 29], involvement [16, 30], gender [20, 31], source expertise [32], and prior knowledge [7, 33].

Table 1. Factors affecting consumer behaviour

\begin{tabular}{|c|c|c|c|c|}
\hline Route & Construct & Definition & $\begin{array}{l}\# \text { of } \\
\text { studies }\end{array}$ & Representative studies \\
\hline \multirow[t]{2}{*}{$\begin{array}{l}\text { Central } \\
\text { route }\end{array}$} & $\begin{array}{l}\text { Argument } \\
\text { quality }\end{array}$ & $\begin{array}{l}\text { Persuasive strength of argu- } \\
\text { ments embedded in an informa- } \\
\text { tional message }\end{array}$ & 36 & {$[34,35]$} \\
\hline & Accuracy & $\begin{array}{l}\text { The correctness of the shared } \\
\text { information }\end{array}$ & 5 & [15] \\
\hline
\end{tabular}




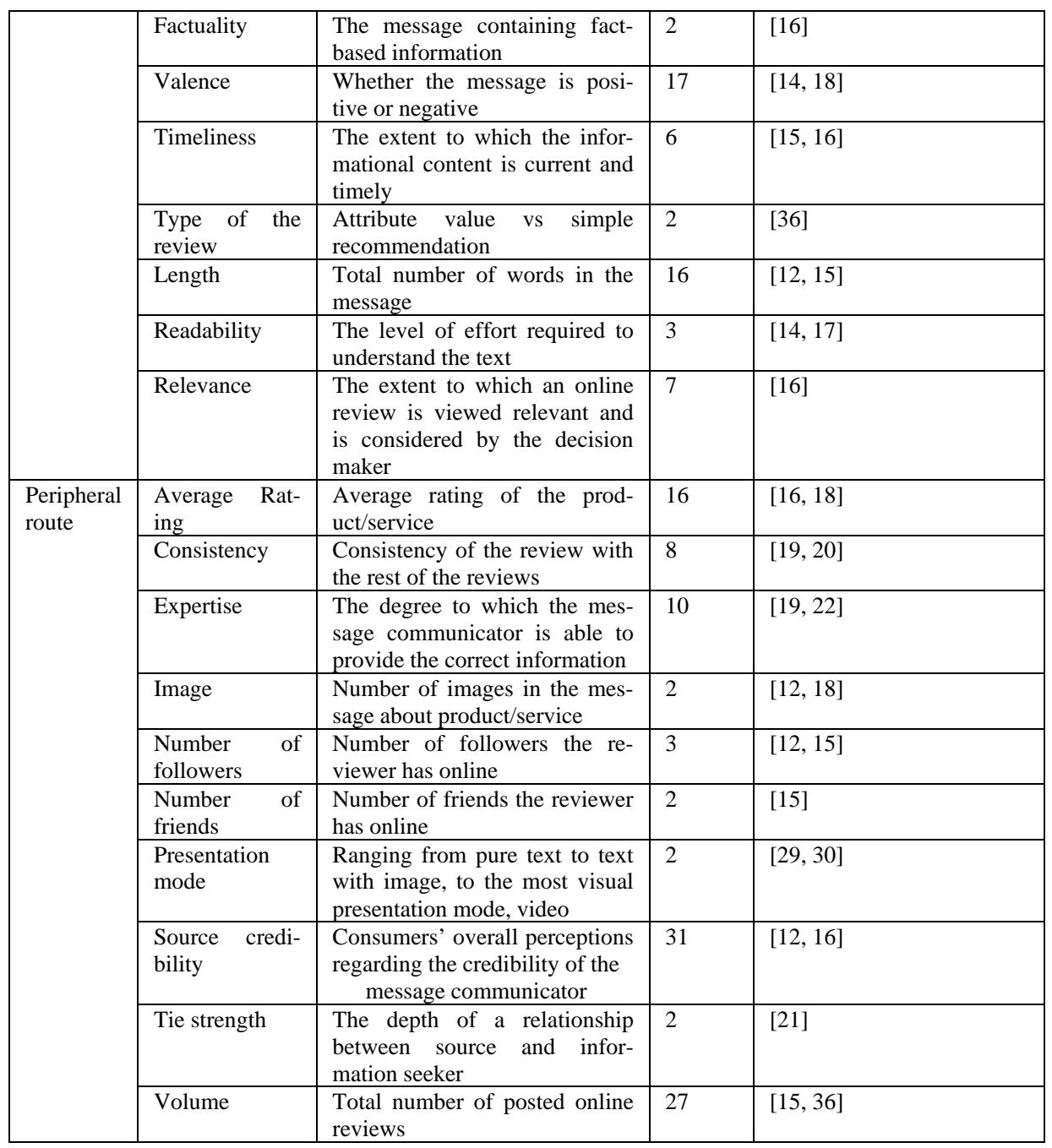

\section{$4 \quad$ Weight analysis}

In order to perform weight analysis, the number of significant results was divided by the total number of times that particular relationship between a given independent and dependent variable had been tested [24, 37]. For example, to calculate the weight for the relationship between argument quality and attitude, 6 (number of significant relationships) was divided by 7 (the total number of studies investigated this relationship), which results in weight 0.857 . Table 3 presents findings from weight analysis for all attributes identified in this review. 
Table 2. Weight analysis

\begin{tabular}{|c|c|c|c|c|c|}
\hline $\begin{array}{c}\text { Independent } \\
\text { variable }\end{array}$ & $\begin{array}{c}\text { Dependent } \\
\text { variable }\end{array}$ & Significant & Non-significant & Total & Weight \\
\hline $\begin{array}{l}\text { Argument } \\
\text { Quality }\end{array}$ & \multirow{3}{*}{ Attitude } & 6 & 1 & 7 & 0.857 \\
\hline $\begin{array}{l}\text { Source credi- } \\
\text { bility }\end{array}$ & & 4 & 4 & 8 & 0.500 \\
\hline Volume & & 4 & 1 & 5 & 0.800 \\
\hline $\begin{array}{l}\text { Argument } \\
\text { Quality }\end{array}$ & \multirow{3}{*}{ Engagement } & 0 & 4 & 4 & 0.000 \\
\hline Attitude & & 3 & 0 & 3 & 1.000 \\
\hline $\begin{array}{l}\text { Source credi- } \\
\text { bility }\end{array}$ & & 3 & 1 & 4 & 0.750 \\
\hline Attitude & \multirow{6}{*}{$\begin{array}{l}\text { eWOM } \\
\text { adoption }\end{array}$} & 3 & 1 & 4 & 0.750 \\
\hline $\begin{array}{l}\text { Argument } \\
\text { Quality }\end{array}$ & & 5 & 0 & 5 & 1.000 \\
\hline $\begin{array}{l}\text { eWOM credi- } \\
\text { bility }\end{array}$ & & 11 & 0 & 11 & 1.000 \\
\hline $\begin{array}{l}\text { eWOM use- } \\
\text { fulness }\end{array}$ & & 13 & 0 & 13 & 1.000 \\
\hline $\begin{array}{l}\text { Source credi- } \\
\text { bility }\end{array}$ & & 3 & 0 & 3 & 1.000 \\
\hline Tie strength & & 2 & 0 & 2 & 1.000 \\
\hline $\begin{array}{l}\text { Argument } \\
\text { Quality }\end{array}$ & \multirow{6}{*}{$\begin{array}{l}\text { eWOM } \\
\text { credibility }\end{array}$} & 12 & 0 & 12 & 1.000 \\
\hline $\begin{array}{l}\text { Average } \\
\text { prod- } \\
\text { uct/service } \\
\text { rating }\end{array}$ & & 7 & 0 & 7 & 1.000 \\
\hline $\begin{array}{l}\text { Consistency of } \\
\text { review }\end{array}$ & & 6 & 1 & 7 & 0.857 \\
\hline $\begin{array}{l}\text { Source exper- } \\
\text { tise }\end{array}$ & & 3 & 1 & 4 & 0.750 \\
\hline $\begin{array}{l}\text { Source credi- } \\
\text { bility }\end{array}$ & & 11 & 0 & 11 & 1.000 \\
\hline Volume & & 2 & 0 & 2 & 1.000 \\
\hline $\begin{array}{l}\text { Argument } \\
\text { Quality }\end{array}$ & \multirow{8}{*}{$\begin{array}{l}\text { Intention to } \\
\text { Buy }\end{array}$} & 9 & 1 & 10 & 0.900 \\
\hline Attitude & & 14 & 0 & 14 & 1.000 \\
\hline Engagement & & 3 & 0 & 3 & 1.000 \\
\hline $\begin{array}{l}\text { eWOM credi- } \\
\text { bility }\end{array}$ & & 7 & 1 & 8 & 0.875 \\
\hline $\begin{array}{l}\text { eWOM use- } \\
\text { fulness }\end{array}$ & & 14 & 2 & 16 & 0.875 \\
\hline $\begin{array}{l}\text { Source credi- } \\
\text { bility }\end{array}$ & & 3 & 3 & 6 & 0.500 \\
\hline $\begin{array}{l}\text { Type of the } \\
\text { review }\end{array}$ & & 1 & 1 & 2 & 0.500 \\
\hline Volume & & 12 & 4 & 16 & 0.750 \\
\hline Accuracy & & 4 & 2 & 6 & 0.667 \\
\hline $\begin{array}{l}\text { Argument } \\
\text { Quality }\end{array}$ & & 12 & 0 & 12 & 1.000 \\
\hline $\begin{array}{l}\text { Consistency of } \\
\text { review }\end{array}$ & & 2 & 0 & 2 & 1.000 \\
\hline Expertise & & 7 & 1 & 8 & 0.875 \\
\hline Factuality & & 1 & 1 & 2 & 0.500 \\
\hline Image count & & 2 & 0 & 2 & 1.000 \\
\hline
\end{tabular}




\begin{tabular}{|c|c|c|c|c|c|}
\hline $\begin{array}{l}\text { Length } \\
\text { review }\end{array}$ & \multirow[t]{11}{*}{$\begin{array}{l}\text { eWOM } \\
\text { usefulness }\end{array}$} & 16 & 3 & 19 & 0.842 \\
\hline $\begin{array}{ll}\begin{array}{l}\text { Number } \\
\text { followers }\end{array} & \text { of } \\
\end{array}$ & & 1 & 2 & 3 & 0.333 \\
\hline $\begin{array}{l}\text { Number } \\
\text { friends }\end{array}$ & & 2 & 0 & 2 & 1.000 \\
\hline Timeliness & & 5 & 3 & 8 & 0.625 \\
\hline Average rating & & 9 & 2 & 11 & 0.818 \\
\hline $\begin{array}{l}\text { Presentation } \\
\text { mode }\end{array}$ & & 2 & 0 & 2 & 1.000 \\
\hline Readability & & 1 & 2 & 3 & 0.333 \\
\hline Relevance & & 6 & 1 & 7 & 0.857 \\
\hline $\begin{array}{l}\text { Source Credi- } \\
\text { bility }\end{array}$ & & 9 & 3 & 12 & 0.750 \\
\hline Valence & & 15 & 2 & 17 & 0.882 \\
\hline Volume & & 6 & 2 & 8 & 0.750 \\
\hline
\end{tabular}

Based on the classification proposed by Jeyaraj et al. (2006), predictors can be classified as well-utilised and experiments. The predictor is considered "well-utilised" if it was examined five or more times, otherwise, the predictor is considered as "experimental". A well-utilised predictor can be classified as "best predictor" if its weight is equal or greater than 0.8. An experimental predictor can be classified as "promising" if its weight is 1 . Based on the above discussion findings from weight analysis were classified in the following way.

Three factors affecting attitude towards product/service, namely argument quality (examined 7 times, significant 6 times), source credibility (examined 8 times, significant 4 times), and volume (examined 5 times, significant 4 times) are considered wellutilised. Based on the result of weight analysis, argument quality and volume are the best predictors of attitude as they have weights of 0.857 and 0.800 respectively.

Three factors influencing eWOM engagement are defined as experimental predictors: argument quality (examined 4 times, significant 0 times), attitude (examined 3 times, significant 3 times), and source credibility (examined 4 times, significant 3 times). As argument quality has weight equals 1 , it is considered as a promising predictor of eWOM engagement.

Three out of 6 predictors of eWOM adoption are best predictors with weight equals to 1: argument quality (examined 5 times, significant 5 times), eWOM credibility (examined 11 times, significant 11 times), and eWOM usefulness (examined 13 times, significant 13 times). The other three predictors, namely attitude (examined 4 times, significant 3 times), source credibility (examined 3 times, significant 3 times), and tie strength (examined 2 times, significant 2 times) are considered experimental. Source credibility and tie strength are examined less than five times but have weight equals to 1 , which makes them promising predictors of information adoption.

Four out of 6 factors affecting eWOM credibility are examined more than five times and have weight more than 0.8 , which makes them best predictors: argument quality (weight equal 1), average rating (weight equals 1), consistency of review (weight equals 0.857 ) and source credibility (weight equals 1 ). Two other predictors are considered as experimental: attitude (examined 4 times, significant 3 times) and tie 
strength (examined 2 times, significant 2 times). Tie strength has a weight of 1 , thus it is considered as a promising predictor of eWOM credibility.

Six out of 8 predictors of intention to buy are well utilised: argument quality (examined 10 times, significant 9 times), attitude (examined 14 times, significant 14 times), eWOM credibility (examined 8 times, significant 7 times), eWOM usefulness (examined 16 times, significant 14 times), and source credibility (examined 6 times, significant 3 times). Argument quality (weight equals 0.900), attitude (weight equals 1) and eWOM credibility (weight equals 0.875 ) are considered as best predictors of intention to buy, as their weight is more than 0.8 and they were examined 5 or more times. Type of review (examined 2 times, significant 1 time) is considered as experimental predictor and engagement (examined 3 times, significant 3 times) is found to be a promising predictor with the weight equals to 1 .

Ten out of 17 predictors affecting eWOM usefulness are well-utilised, namely accuracy (examined 6 times, significant 4 times), argument quality (examined 12 times, significant 12 times), expertise (examined 8 times, significant 7 times), length of review (examined 19 times, significant 16 times), timeliness (examined 8 times, significant 5 times), average rating (examined 11 times, significant 9 times), relevance (examined 7 times, significant 6 times), source credibility (examined 12 times, significant 9 times), valence (examined 17 times, significant 15 times), and volume (examined 8 times, significant 6 times). Out of nine well utilised predictors, the following predictors have weight more than 0.8 , which makes them best predictors of eWOM usefulness: argument quality (weight equals 1 ), expertise (weight equals 0.875 ), length of review (weight equals 0.842 ), average rating (weight equals 0.818 ), relevance (weight equals 0.857), and valence (weight equals 0.882).

Finally, seven predictors of eWOM usefulness are experimental as they were examined less than 5 times: consistency of review (examined 2 times, significant 2 times), factuality (examined 2 times, significant 1 time), image count (examined 2 times, significant 2 times), number of followers (examined 3 times, significant 1 time), number of friends (examined 2 times, significant 2 times), presentation mode (examined 2 times, significant 2 times), and readability (examined 3 times, significant 1 time). Out of these experimental predictors, four have weight equals to 1 , which makes them promising predictors of eWOM usefulness: consistency of review, image count, number of friends, and presentation mode.

\section{Discussion}

Taking into consideration the growing number of studies employing ELM to study eWOM persuasiveness, it is important to discuss and analyse their collective findings. Figure 1 depicts the diagrammatic representation of the factors affecting consumer behaviour using ELM with their corresponding weight by employing the results of weight analysis. The findings suggest that best predictors such as volume, argument quality, consistency of review, source credibility, expertise, length of the review, average rating, relevance, source credibility, and valence should be included in eWOM research. Promising predictors of engagement (attitude), eWOM adoption 
(source credibility, tie strength), eWOM credibility (volume), intention to buy (engagement) and eWOM usefulness (image count, number of friends, presentation mode) should be included in future empirical research in order to evaluate their overall performance.

Most of the eWOM studies employing ELM as a theoretical foundation focused on characteristics of the message source or content of the message. However, limited number of studies investigated the impact of individual characteristics on information processing. Thus, future research needs to consider factors such as age, gender, level of education, trust tendency to name a few. This will advance our understanding of information processing by individuals.

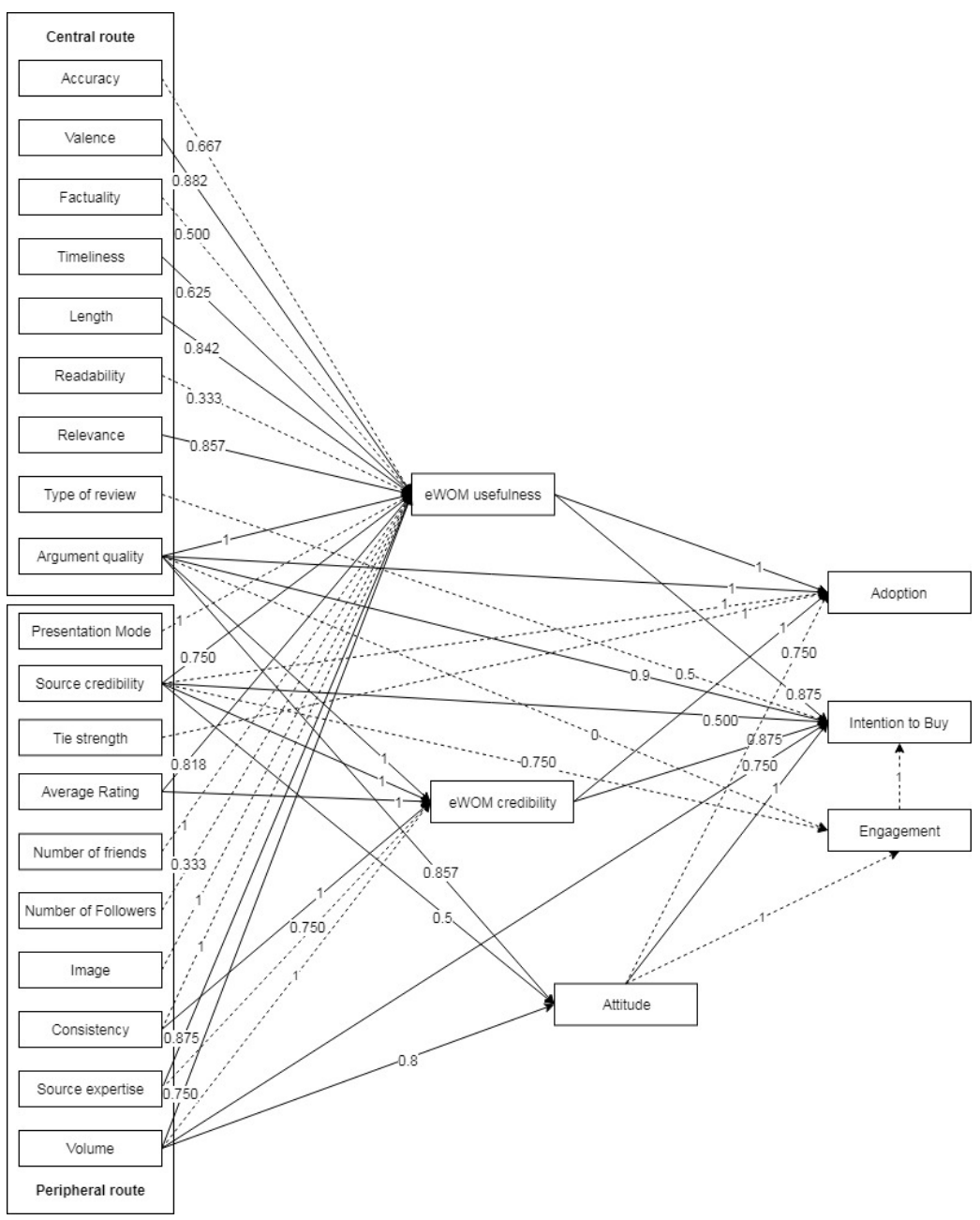

Figure 1. Factors affecting the persuasiveness of eWOM communications and consumer behavior

Note:- - $>$ experimental predictors; $\longrightarrow$ well-utilised predictors. 


\section{Conclusion}

This research aimed to evaluate the use of ELM in the context of eWOM research by performing weight analysis of existing research findings. This aim was reached by identifying and analysing relevant and important studies on eWOM that used ELM as a theoretical foundation. The weight analysis was performed by identifying a number of significant and non-significant relationships between studied variables.

This research provides some implications for researchers and practitioners. This study builds a framework for future research identifying peripheral and central route factors and their impact on consumer behaviour. The proposed framework provides the overall picture of persuasive eWOM communication by using ELM. Scholars looking further into the factors affecting information processing of eWOM messages can employ the results of this study in order to make more informed decisions regarding inclusion of factors in their research. Practitioners are advised to carefully evaluate the traditionally utilised predictors and pay more attention to the best predictors- volume, argument quality, consistency of review, source credibility, expertise, length of the review, average rating, relevance, source credibility, and valence.

The current study has some limitations. First, this study used only Web of Science, Scopus and EBSCO databases for collection of study, which can limit the number of research outputs available for weight analysis. Future research should also employ any other available datasets. Second, this research employed only weight analysis without conducting meta-analysis. Conducting meta-analysis can assist researchers in evaluation of the significance of the studied relationships based on the effect size statistics. Additionally, outcomes of meta-analysis could strengthen the findings of weight analysis [38]. Thus, future studies could perform both types of analysis of factors affecting consumer behaviour.

\section{References}

1. Tsao, W.-C., Hsieh, M.-T.: eWOM persuasiveness: do eWOM platforms and product type matter? Electronic Commerce Research 15, 509-541 (2015)

2. Ismagilova, E., Dwivedi, Y.K., Slade, E., Williams, M.D.: Electronic word of mouth (eWOM) in the marketing context: A state of the art analysis and future directions. (2017)

3. King, R.A., Racherla, P., Bush, V.D.: What we know and don't know about online word-ofmouth: A review and synthesis of the literature. Journal of interactive marketing 28, 167-183 (2014)

4. Kaemingk, D.: 20 online review stats to know in 2019. Qualtrics. https://www. qualtrics. com/blog/onlinereview-stats/(accessed Feb. 29, 2020) (2019)

5. Teng, S., Khong, K.W., Goh, W.W.: Conceptualizing persuasive messages using ELM in social media. Journal of Internet Commerce 13, 65-87 (2014) 
6. Kitchen, P.J., Kerr, G., Schultz, D.E., McColl, R., Pals, H.: The elaboration likelihood model: review, critique and research agenda. European Journal of Marketing (2014)

7. Kim, J., Lee, C.: Examining the role of relationship factors on eWOM effectiveness in social media. International Journal of Internet Marketing and Advertising 11, 103-123 (2017)

8. Wang, P.: Understanding the influence of electronic word-of-mouth on outbound tourists' visit intention. In: Conference on e-Business, e-Services and e-Society, pp. 33-45. Springer, (Year)

9. Petty, R.E., Cacioppo, J.T.: The elaboration likelihood model of persuasion. Communication and persuasion, pp. 1-24. Springer (1986)

10.Baek, H., Ahn, J., Choi, Y.: Helpfulness of online consumer reviews: Readers' objectives and review cues. International Journal of Electronic Commerce 17, 99-126 (2012)

11.Sussman, S.W., Siegal, W.S.: Informational influence in organizations: An integrated approach to knowledge adoption. Information systems research 14, 47-65 (2003)

12.Cheng, Y.-H., Ho, H.-Y.: Social influence's impact on reader perceptions of online reviews. Journal of Business Research 68, 883-887 (2015)

13.Hussain, S., Ahmed, W., Jafar, R.M.S., Rabnawaz, A., Jianzhou, Y.: eWOM source credibility, perceived risk and food product customer's information adoption. Computers in Human Behavior 66, 96-102 (2017)

14.Agnihotri, A., Bhattacharya, S.: Online review helpfulness: Role of qualitative factors. Psychology \& Marketing 33, 1006-1017 (2016)

15.Aghakhani, N., Oh, O., Gregg, D.: Beyond the review sentiment: The effect of review accuracy and review consistency on review usefulness. (2017)

16.Filieri, R., Hofacker, C.F., Alguezaui, S.: What makes information in online consumer reviews diagnostic over time? The role of review relevancy, factuality, currency, source credibility and ranking score. Computers in Human Behavior 80, 122-131 (2018)

17.Mousavizadeh, M., Koohikamali, M., Salehan, M.: The effect of central and peripheral cues on online review helpfulness: A comparison between functional and expressive products. (2015)

18.Srivastava, V., Kalro, A.D.: Enhancing the helpfulness of online consumer reviews: The role of latent (content) factors. Journal of Interactive Marketing 48, 33-50 (2019)

19.Cheung, C.M.-Y., Sia, C.-L., Kuan, K.K.: Is this review believable? A study of factors affecting the credibility of online consumer reviews from an ELM perspective. Journal of the Association for Information Systems 13, 2 (2012)

20.Luo, C., Wu, J., Shi, Y., Xu, Y.: The effects of individualism-collectivism cultural orientation on eWOM information. International Journal of Information Management 34, 446456 (2014)

21.Mahapatra, S., Mishra, A.: Acceptance and forwarding of electronic word of mouth. Marketing Intelligence \& Planning (2017)

22.Thomas, M.-J., Wirtz, B.W., Weyerer, J.C.: DETERMINANTS OF ONLINE REVIEW CREDIBILITY AND ITS IMPACT ON CONSUMERS'PURCHASE INTENTION. Journal of Electronic Commerce Research 20, 1-20 (2019)

23.Rana, N.P., Dwivedi, Y.K., Williams, M.D.: A meta-analysis of existing research on citizen adoption of e-government. Information Systems Frontiers 17, 547-563 (2015) 
24.Ismagilova, E., Slade, E.L., Rana, N.P., Dwivedi, Y.K.: The effect of electronic word of mouth communications on intention to buy: A meta-analysis. Information Systems Frontiers 124 (2019)

25.Alsudairi, M., Dwivedi, Y.K.: A multi-disciplinary profile of IS/IT outsourcing research. Journal of Enterprise Information Management (2010)

26.Hughes, D.L., Dwivedi, Y.K., Rana, N.P., Simintiras, A.C.: Information systems project failure-analysis of causal links using interpretive structural modelling. Production Planning \& Control 27, 1313-1333 (2016)

27.Slade, E.L., Williams, M.D., Dwivedi, Y.K.: Devising a research model to examine adoption of mobile payments: An extension of UTAUT2. The Marketing Review 14, 310-335 (2014)

28.Ketron, S.: Investigating the effect of quality of grammar and mechanics (QGAM) in online reviews: The mediating role of reviewer crediblity. Journal of Business Research 81, 51-59 (2017)

29.Xu, P., Chen, L., Santhanam, R.: Will video be the next generation of e-commerce product reviews? Presentation format and the role of product type. Decision Support Systems 73, 85-96 (2015)

30.Xu, P., Chen, L., Wu, L., Santhanam, R.: Visual Presentation Modes in Online Product Reviews and Their Effects on Consumer Responses. (2012)

31.Chong, A.Y.L., Khong, K.W., Ma, T., McCabe, S., Wang, Y.: Analyzing key influences of tourists' acceptance of online reviews in travel decisions. Internet Research (2018)

32.Evertz, L., Kollitz, R., Süß, S.: Electronic word-of-mouth via employer review sites-the effects on organizational attraction. The International Journal of Human Resource Management 1-30 (2019)

33.Cao, X., Liu, Y., Zhu, Z., Hu, J., Chen, X.: Online selection of a physician by patients: Empirical study from elaboration likelihood perspective. Computers in Human Behavior 73, 403-412 (2017)

34.Han, S., Li, Y., Jiang, Y., Zhao, X.: Exploring the persuasion effect of restaurant food product online reviews on consumers' attitude and behavior. In: Proceedings of the 2018 International Conference on Internet and e-Business, pp. 57-60. (Year)

35.Wang, P.: Exploring the influence of electronic word-of-mouth on tourists' visit intention: A dual process approach. Journal of Systems and Information Technology (2015)

36.Park, D.-H., Kim, S.: The effects of consumer knowledge on message processing of electronic word-of-mouth via online consumer reviews. Electronic commerce research and applications 7, 399-410 (2008)

37.Jeyaraj, A., Rottman, J.W., Lacity, M.C.: A review of the predictors, linkages, and biases in IT innovation adoption research. Journal of information technology 21, 1-23 (2006)

38.Jeyaraj, A., Dwivedi, Y.K.: Meta-analysis in information systems research: Review and recommendations. International Journal of Information Management 55, 102226 (2020) 